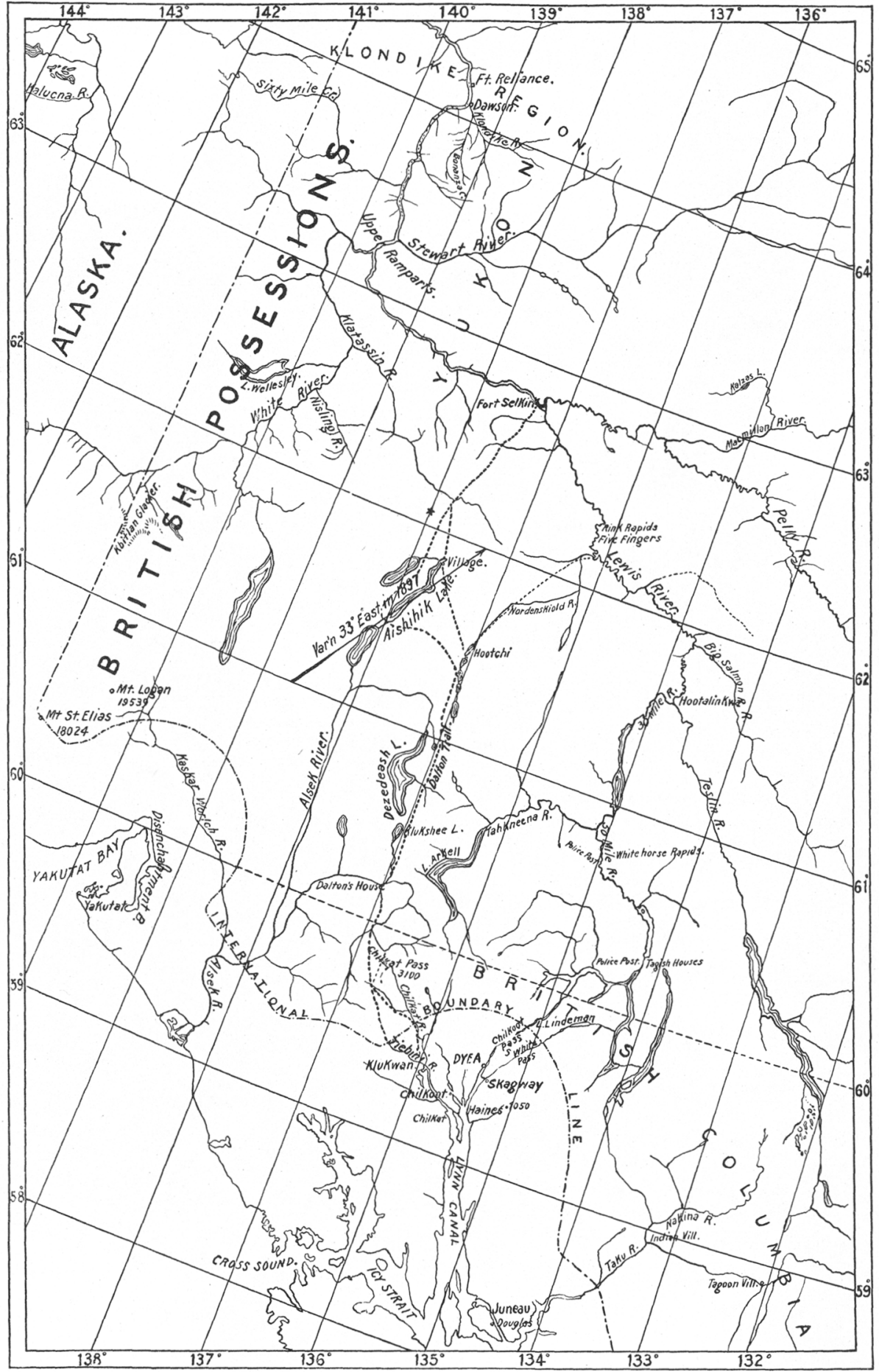




\title{
GLACIAL PHENOMENA IN THE CANADIAN YUKON DISTRICT
}

\author{
BY J. B. TYRREILI
}

(Read before the Society December 29, 1898)

\section{CONTENTS}

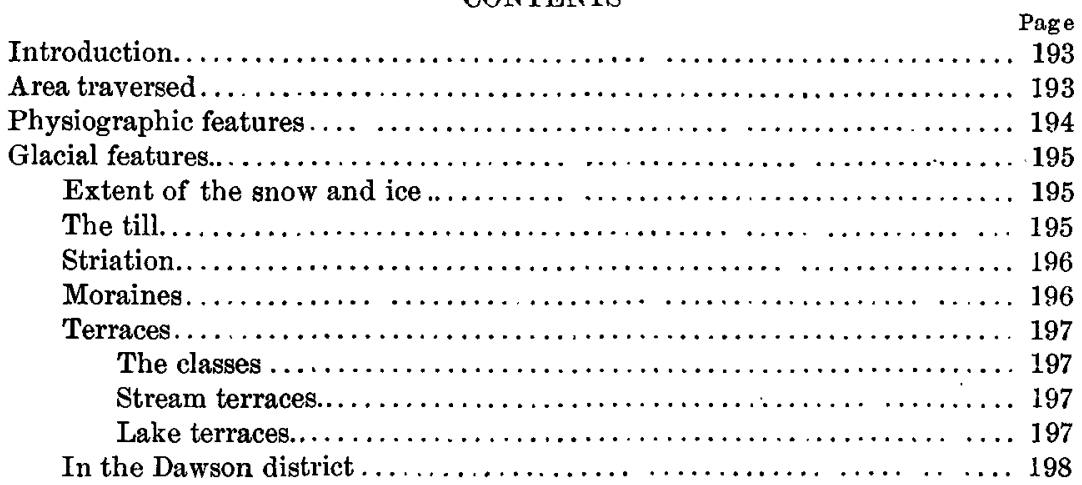

\section{INTRODUCTION}

Last summer, while traveling on horseback and on foot through the southwestern portion of the Yukon district and the extreme northwestern parts of British Columbia, many opportunities presented themselves for observing glacial phenomena--opportunities such as would hardly occur to those who were passing through the same country in boats on some of the many streams which flow along the bottoms of the many deep and wide valleys.

\section{Area Traversed}

My route lay to the west of the Lewis river, on and in the vicinity of what is generally known as the Dalton trail-that is, up the valleys of the Chilcat and Klahina or Tlehini rivers, over the summit of the Coast or Chilcat range, and down a wide and continuous valley which, after being occupied in succession by parts of several streams, forks, the easterly 
portion forming the valley of the Nordenskiold river, which joins the Yukon a short distance above Five-fingers rapids, while the westerly valley passes northward by Aishihik lake to Nisling river, down that river to White river, and thence down the White to the point where it flows into the Yukon river.

In addition to the trip outlined, a short time was spent farther north on the Klondike river and its tributaries.

\section{Physiographic Features}

Toward the south this country is a mass of steep, rocky, ungraded mountains, among which tower the giant peaks of Hubbard, Vancouver, Logan, and Saint Elias. These mountains lie to the westward of the great valley of the Lynn canal and Chilcat river, and form a range which would appear to be quite distinct from the granitic "Coast range," which forms the western wall of the continent farther south, in both Alaska and British Columbia. In order to distinguish this range more clearly, I propose for it the name "Chilcat range," associating it with one of the most powerful tribes of Indians on the Alaskan coast.

This range is bounded on the south and southwest by the Pacific ocean and toward the north and northeast by the great Chilcat-Alsek valley, which extends inland from the western arm of the Lynn canal, following more or less closely the line of contact of the granite to the northeast and the schists and limestones to the southwest. The average width of the range is between 80 and 100 miles.

Much of the range is buried in extensive snowfields, from which glaciers radiate in all directions, both toward the coast and toward the interior. A magnificent view of this country was obtained last summer from the summit of Farview mountain, a high peak south west of Aishihik lake, and it presented the appearance of a vast white plain, through which the higher peaks rose in dark relief, mount Saint Elias appearing for a few moments from beneath the clouds. It is thus a vast snow-clad plateau, lying close to the Pacific coast, in one of the regions of greatest precipitation on the American continent.

Farther north the country is also mountainous, but the mountains are much more rounded, their slopes are easier, and their sides show comparatively few broken, ungraded cliffs. As a rule, they rise from 3,000 to 4,000 feet above the bottoms of the deeper intervening valleys. Standing on one of the summits, a great number of similar mountains may be seen on every side, all about the same height and probably cut out of the same extensive pre-Tertiary peneplain.

Lakes, in some cases of large size, lie in the bottoms of the valleys; 
but, as far as my observations went, they are confined exclusively to those parts of the country which have been more or less completely covered by glaciers during the Pleistocene epoch. Beyond the limits of the glaciated region no lakes were seen.

\section{Glactal Features}

\section{EXTENT OF THE SNOW AND ICE}

While the Chilcat mountains are almost buried in snow throughout the year, very little snow is to be seen in summer on this "interior plateau," and any small glaciers that do exist are in some of the higher mountains close to the Chilcat range.

Though the ice-fields of the present day are confined almost entirely to the Chilcat mountains, the ice-fields of the Glacial period were much more extensive, for they spread northward as far as Five-fingers rapids on the Lewis river and to a short distance beyond Aishihik lake in the A ishihik valley. The northern limit of glaciation is not by any means an approximately straight line, for it indicates the lengths to which the glaciers filled the valleys rather than the even margin of a great confluent ice-sheet. The higher mountains rose above the level of the ice, just as they do at the present time in the Chilcat range, and small glaciers moved down their sides to join the larger glaciers in the valleys.

The Chilcat-Alsek valley gives a beautiful idea of the former depth or thickness of the ice. The bottom of the valley is almost flat, and the sides rise in gentle willow-covered slopes for 2,000 feet or more to the foot of the ungraded rocky peaks on either hand. Rock is everywhere exposed above this line, while below it rock exposures are comparatively rare, and the country is underlain by a loose unassorted till, on which willows and dwarf birches grow in dense thickets. As seen from the bottom of the valley, the upper limit of the willow-covered slope forms a fairly regular line along the sides of the mountains, and indicates approximately the depth to which the ice-sheet filled the valley, a depth which here varied from 2,000 to 3,000 feet. Above this line the higher mountains rise in broken, jagged peaks, while any lower mountains which do not rise above the level of the top of the till have their summits evenly rounded and unbroken.

THE TILL

The till which fills the bottom of this valley, often to depths of 100 feet or more, is a mass of unassorted material; in part local and in part derived from a distance. It contáins pebbles and boulders, usually 
more or less rounded in shape, some of which are striated while the great majority are smooth and without glacial markings. In general character it is very similar to the till which underlies so much of the plains of northwestern Canada between the edge of the Archean nucleus and the Rocky mountains. Similar till was found to underlie the bottoms and sides of most of the valleys everywhere throughout the glaciated area in the Yukon district, having evidently been formed as a ground moraine beneath the great sheets of ice.

\section{STRIATION}

Striated rock surfaces were not very often seen, for where the rock is exposed it has usually become rough through weathering, but they were recognized in a few places on the interior plateau, and in every instance they indicated a direction of ice-movement motion from the coast toward the interior or essentially simply a wider extension of the glacial conditions which exist in the region at the present time. In this extension toward the interior the ice for the most part followed the great valleys which trench the surface of the country in a general north-and-south direction, and therefore the movement of the ice was generally northward.

Close to the coast the glaciers flowed seaward and filled the many deep valleys which descend from the mountains to the Pacific ocean. In the Skagway valley the White Pass railroad while constructing its line has cut a notch along a rocky hillside which has been beautifully smoothed and scored by such a glacier.

\section{MORAINES.}

Lateral moraines occasionally form conspicuous features along the sides of the mountains, often running as long, narrow lines of boulders or transported material, swaying slightly up and down with the irregularities of the surface, and in places running into water-worn terraces where some small stream bas thrown its load of gravel against the side of the glacier. A very well marked moraine of this character extends along the west side of the valley of Aishihik lake at about 1,500 feet above the water. It is a fairly regular ridge of boulders, along the crest of which, in some places, runs the horse trail from Fort Selkirk southward to Pyramid harbor. Above it the surface of the mountain consists of a fairly even, regular incline of decomposed rock, while below it is a till-covered slope, often broken into very lumpy, irregular hills. Lateral moraines were also traced down the side of a deep valley northwest of 'Aishihik lake as well as in some other places. 
Terminal moraines were recognized in a few places, but they scarcely formed as conspicuous features as one would have been inclined to expect. From lake Ajshihik northward for about 12 miles in the bottom of the valley is a terminal moraine area, represented in places by irregular hills of boulders, which was formed at the foot of the Aishihik lobe of the great ice-sheet when it had reached its extreme northern limit. The low stony hills east of the Hoochi lakes represent another moraine, while the stony hills at the mouth of the west branch of Nordenskiold river are clearly morainic in character ; but they also show many signs of water action, and merge into the extensive pitted plain or terrace which extends along the banks of the Lewis river from the mouth of the Nordenskiold to Rink rapids.

\section{TERRACES}

The classes.-The terraces occurring in this region are of two kinds, namely, stream terraces and lake terraces.

Stream terraces.-Stream terraces have chiefly been formed by torrential rivers, loaded with detritus, flowing from the feet of the glaciers, and are most conspicuous in the larger valleys beyond the limits of the glaciated area, as, for instance, in the valleys of Lewis and Nisling rivers; but as the glaciers diminished in size and their fronts retired up the valleys, gravels and sands were deposited in the bottoms of the valleys which had previously been occupied by the ice, and thus terraces were formed on the low lands in the region which had been covered with glaciers.

Lake terraces.-Lake terraces are confined exclusively to the glaciated area, none having been recognized beyond the northern limits to which the vast ice-sheets of the Glacial period extended. They usually consist of fine sand, silt, or rock flour, which is often of whitish color and commonly has the appearance of the finer material carried down into bodies of quiet water by glacial streams. These terraces sometimes extend 2,000 feet or more up the sides of the mountains, especially in wider parts of some of the great valleys which traverse the country. Such terraces are beautifully shown on the sides of the mountains around lake Dezedeash. There can be no doubt that the outlets to the valley were filled with ice, and that the deep lake which existed here, around the shores of which the terraces of white silt were formed, was in part walled in by the fronts of glaciers.

Similar terraces were seen in many other places, and often several would descend in regular series, until it was difficult to distinguish the lowest from the higher and finer of the stream terraces. It is confidently believed, however, that all the white silt terraces in that portion of the Yukon district examined were formed in ice-dammed lakes and furnish 
no evidence whatever of marine conditions or of recent submergence of the land. Any regularity in height of the highest terraces is easily accounted for by the moderately regular average thickness of the ice-sheet when the lakes were in existence.

\section{IN THE DAWSON DISTRICT}

As small glaciers now exist in the valleys of the mountains north of the Chilcat range, so small glaciers formerly existed in some of the mountain valleys north of the main ice-sheet of the Glacial period. Such glaciers existed in the valleys of Eldorado and Bonanza creeks, near Dawson, and flowed down these valleys at least to some point below the confluence of the two creeks. Beautiful glacial striæ were seen on the hard quartzose rocks at the mouth of Big Skookum gulch, on the west side of Bonanza creek, which had been made by this glacier, furnishing indisputable evidence of its presence. A lateral moraine of this glacier, often containing pebbles and small boulders of distinct glacial shapes, extends along the side of the valley from 150 to 200 feet above the creek, and in it are some of the rich bench claims on Eldorado hill and at French gulch, and the sand and gravel in the bottom of the valley is well rounded, but roughly assorted material, such as is constantly washed down and distributed by glacial streams. 